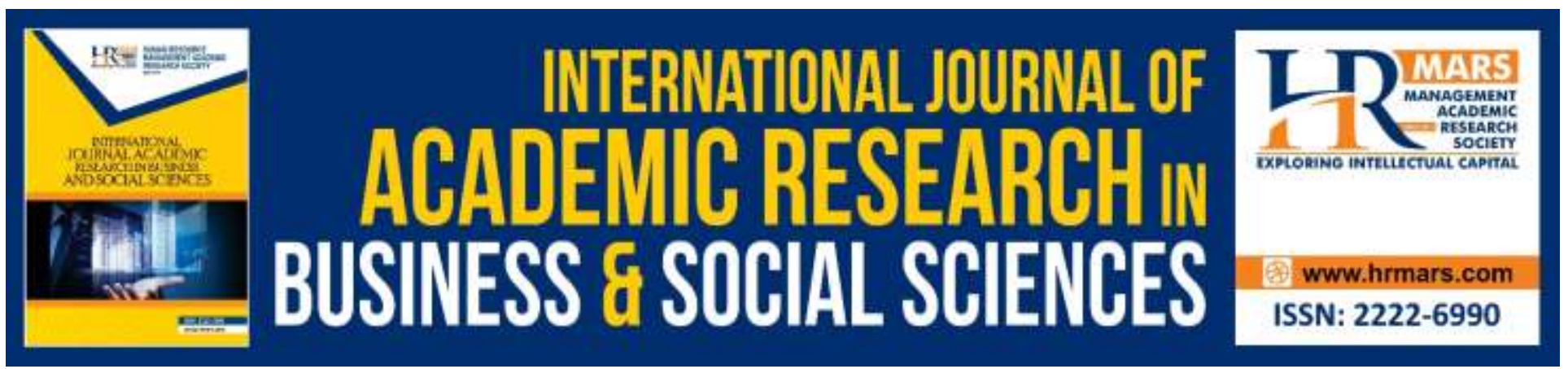

\title{
Poverty and the Social Problems
}

\section{Zaihana Manshor, Shuhairimi Abdullah, Abu Bakar Hamed}

To Link this Article: http://dx.doi.org/10.6007/IJARBSS/v10-i3/7076

DOI:10.6007/IJARBSS/v10-i3/7076

Received: 02 February 2020, Revised: 22 February 2020, Accepted: 12 March 2020

Published Online: 24 March 2020

In-Text Citation: (Manshor et al., 2020)

To Cite this Article: Manshor, Z., Abdullah, S., \& Hamed, A. B. (2020). Poverty and the Social Problems. International Journal of Academic Research in Business and Social Sciences, 10(3), 614-617.

\section{Copyright: (C) 2020 The Author(s)}

Published by Human Resource Management Academic Research Society (www.hrmars.com)

This article is published under the Creative Commons Attribution (CC BY 4.0) license. Anyone may reproduce, distribute, translate and create derivative works of this article (for both commercial and non-commercial purposes), subject to full attribution to the original publication and authors. The full terms of this license may be seen at: http://creativecommons.org/licences/by/4.0/legalcode

Vol. 10, No. 3, 2020, Pg. 614 - 617

Full Terms \& Conditions of access and use can be found at http://hrmars.com/index.php/pages/detail/publication-ethics 


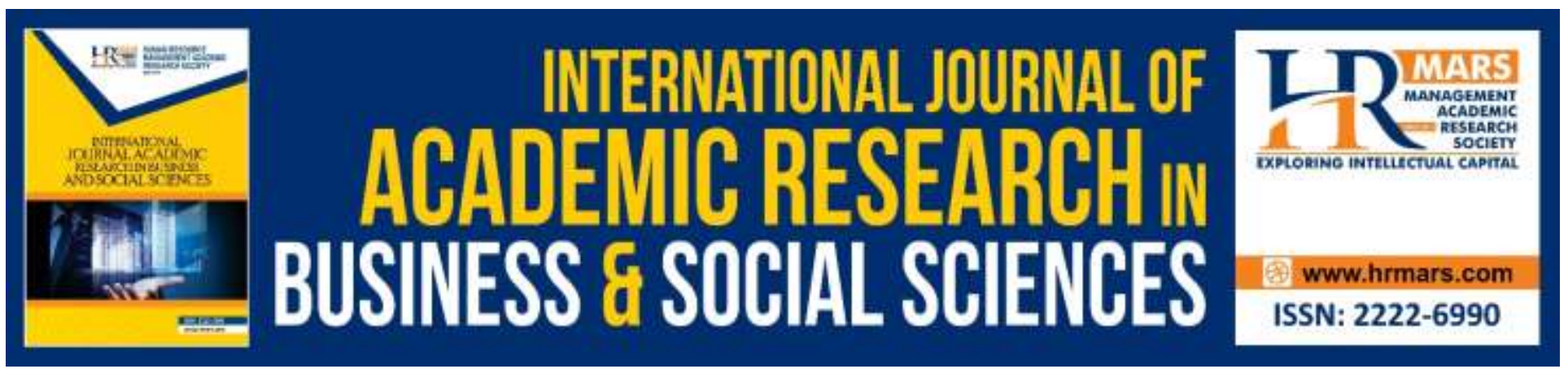

\title{
Poverty and the Social Problems
}

\author{
Zaihana Manshor ${ }^{\mathrm{a}}$, Shuhairimi Abdullah ${ }^{\mathrm{b}}$, Abu Bakar Hamed

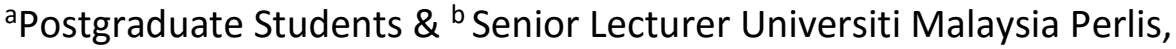 \\ 'Senior Lecturer Universiti Utara Malaysia \\ Email: zaihanamans@yahoo.com ${ }^{\mathrm{a}}$
}

\begin{abstract}
Absract
This concept paper discusses the issue of poverty in society. There are many factors that lead to this situation. In fact, unemployment is seen to contribute to this poverty problem. Statistics on unemployment rates among community are also increasing day by day. The paper also outlines the continuity between poverty and social problems among the society today, especially youth. Furthermore, the methods used for this conceptual paper by using secondary data sources in online databases and library collections. It is hoped that the findings of this study will contribute to the existing social literature, particularly in relation to studies on the issue of poverty from emerging socio-economic perspectives.
\end{abstract}

Keyword: Poverty, Social Problems, Social Issue, Unemployment, Youth

\section{Introduction}

In the era of globalization, which is increasingly challenging now, the modern trend is evolving in tandem with the sophistication of technology and the development of a country. However, the civilizational life of a society becomes uneven when we are often surprised by the news of moral depravity and social problems in society now. Undeniable, achievement in the aspects of economy, education, politics, sports and other fields are very boast and inspiring but we still fail in the social aspect. These problems are closely related to each other. The causes and factors that contribute to each of these things need to be emphasized and examined so that these symptoms can be adequately contained. All parties have a role to play together. This is because united we stand, divided we fall.

\section{Poverty}

Literally, there are some definitions and dimensions of poverty. Generally, poverty is likened to a state of income of a family or individual who does not qualify for a living standard of living in a community. Poverty has been defined, measured and investigated about the causes or factors that contribute from various aspects of life. Hence, programs to address poverty need to be implemented where it emphasizes on the economic, social and political contexts that are closely related to the poor (Suzuki, Pramono \& Rufidah, 2017). Meanwhile, Liu, Liu, \& Zhou (2017) stated that imbalances in 
INTERNATIONAL JOURNAL OF ACADEMIC RESEARCH IN BUSINESS AND SOCIAL SCIENCES

Vol. 10, No. 3, March, 2020, E-ISSN: 2222-6990 @ 2020 HRMARS

socio-economic development could contribute to the existence of poor settlements. In addition, there are various views of economists on the dimensions of poverty. Wagle (2018) argues that economic prosperity is a measure of poverty to a poverty line based on the definition of absolute, subjective and relative concepts. Among the elements used are income, consumerism and welfare.

\section{Social Problems}

Social problems in society are increasing from day to day. Starting from juvenile cases among students in school until criminal cases are much more worsening. According to Taftazani (2017), a society is considered to have a social problem when the situation in the community becomes severe, unstoppable and unsafe so that solutions come to address these symptoms. The cause of these problems comes from various aspects of life. Citing a line of the hadith that states that poverty can lead to disbelief. In this context, the meaning of disbelief is through moral misconduct and disobedience to religious, shari'a law and demands (Hafid, 2011). Therefore, in order to fulfill their desperate need they are able to do wrong and harm. Bahrom (2004) has relate the family economy as a major cause to social problems in today's society. Based on a survey conducted at the East Coast's moral rehabilitation center, the majority of juvenile trainers come from poor families earning less than RM500. This group was caught in the urge to meet their needs and had to be involved in a crime scene. The proof is that most of these juveniles are involved in stealing, drug trafficking, escape from home and others related to socio-economic families. In fact, unemployment is closely related to the increased risk of poverty (Gallie, Paugam \& Jacobs, 2003) and this will lead to the increase of social problems (Hafid, 2011). In addition, Allmendinger \& Ludwig-Mayerhofer (2017) also have the same opinion and added that unemployment is also often associated with problems such as crime, illness, right-wing extremism, suicide, and so on. In 2017, the Department of Statistics Malaysia revealed that the index crime ratio for 100,000 Malaysians recorded a figure of 309.7. Based on the figure, six states recorded index crimes above the national level, Wilayah Persekutuan (716.9), Selangor (408.6) Negeri Sembilan (356.6), Melaka (339.2), Pulau Pinang (318.3) and Kedah (315.3).

\section{Conceptual Framework}

Based on the discussion, there are conceptual framework proposed in this concept paper. The framework indicates that there are relationship between unemployment, poverty and social problems. Based on the framework, the root cause of poverty is the onset of rising unemployment issues. Subsequently, an increase in the level of poverty contributes to increasingly uncontrolled social problems. This is becoming more severe when this unstoppable social problems contributes to unemployment issues in the future.

Figure 1. Relationship between Poverty, Unemployment and Social Problems

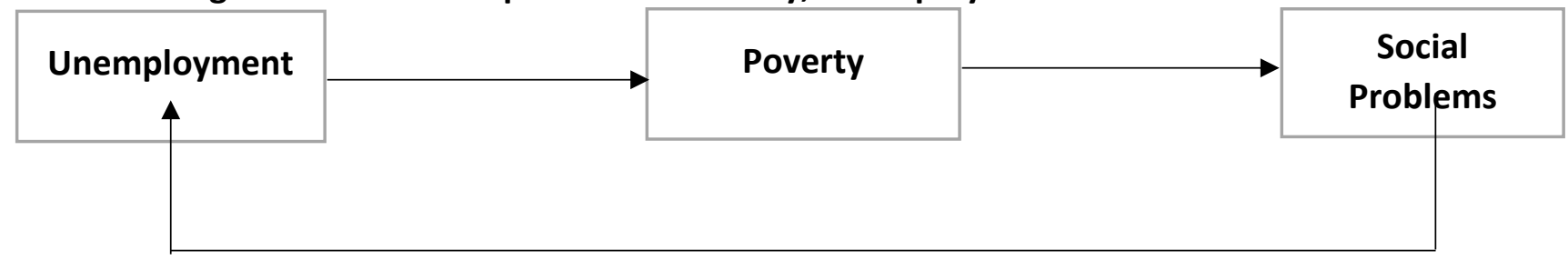


INTERNATIONAL JOURNAL OF ACADEMIC RESEARCH IN BUSINESS AND SOCIAL SCIENCES

Vol. 10, No. 3, March, 2020, E-ISSN: 2222-6990 @ 2020 HRMARS

\section{Conclusion}

In the nut shell, there are many factors contributing to social problems, but the most one is poverty. Undeniable, poverty is a biggest issue today in this century. There are many approaches and theory used to understand and define it. To eliminate poverty is impossible, but we are able to reduce it regularly. Moreover, the high and uncontrolled unemployment rate also becomes the cause of this poverty issue. It is a great responsibility for the government to make greater efforts in providing various initiatives such as more job opportunities as well as financial assistance to start up a business. On the other hand, another alternative that can be applied is social protection which is giving a better life to the poor so that they can survive in the challenging world (Khairullina, Ustinova, Sadykova, Tretyakova \& Bogdanova, 2016). Ironically, these problems are keep on relating to each other. Problems are interconnected and become a symbiosis in the lives of the people.

\section{Corresponding Author}

Zaihana Manshor

Postgraduate Students, School of Human Development and Techocommunication (iKOM), UNIMAP, Perlis. No. Tel: 017-4700467

(Correspondence: zaihanamans@yahoo.com)

\section{References}

Allmendinger, J., \& Ludwig-Mayerhofer, W. (2017). Unemployment as a social problem. The Blackwell encyclopedia of sociology. https://doi.org/10.1002/9781405165518.wbeosu003

Bahrom, H. (2004). Remaja, Kemiskinan dan Juvana Suatu Realiti? Seminar Antarabangsa Nilai Dalam Komuniti Pasca Modenisme (SIVIC 2004), (September 2004), 1-13.

Gallie, D., Paugam, S., \& Jacobs, S. (2003). Unemployment, Poverty and Social Isolation: Is There a Vicious Circle of Social Exclusion? European Societies. https://doi.org/10.1080/1461669032000057668

Hafid, E. (2011). Kemiskinan (Al-Faqr) dalam perspektif hadis. Jurnal Al-Hikmah, 12 (1), 11-27.

Jabatan Perangkaan Malaysia. (2018). Siaran Akhbar Statistik Jenayah, Malaysia, 2018. 1-5.

Khairullina, N. G., Ustinova, O. V., Sadykova, H. N., Tretyakova, O. V., \& Bogdanova, J. Z. (2016). Social Protection of The Poverty: Problems and Solutions. International Journal of Economics and Financial Issues.

Liu, Y., Liu, J., \& Zhou, Y. (2017). Spatio-Temporal Patterns of Rural Poverty in China and Targeted Poverty Alleviation Strategies. Journal of Rural Studies. https://doi.org/10.1016/j.jrurstud.2017.04.002

Suzuki, Y., Pramono, S., \& Rufidah, R. (2017). Islamic Microfinance and Poverty Alleviation Program: Preliminary Research Findings from Indonesia. Journal of Islamic Economics and Finance. https://doi.org/10.22373/share.v5i1.910

Taftazani, B. M. (2017). Masalah Sosial dan Wirausaha Sosial. Share: Social Work Journal. https://doi.org/10.24198/share.v7i1.13822

Wagle, U. (2018). Rethinking Poverty: Definition and Measurement. International Social Science Journal. https://doi.org/10.1111/issj.12192 